\title{
Development of the Readiness and Success Model for Assessing the Information System Integration
}

\author{
A’ang Subiyakto \\ Department of Information System \\ Syarif Hidayatullah State Islamic University Jakarta \\ Tangerang Selatan, Indonesia \\ Email: Aang_subiyakto@uinjkt.ac.id
}

\begin{abstract}
This study reports how to combine a technology readiness model within an information system (IS) success model in the context for assessing the readiness and success factors of an IS integration. As it is indicated by many IS studies, that most of the IS models are developed by adopting, combining, and adapting the previous ones. The researcher developed the model based on the input-process-output logic and the processional and causal model of the IS success models. The developed model was structured within nine variables and 44 indicators. The influence paths among the variables were presented by 23 links. In respect of the research implementation, the author has also broken down the model into its assessment instrument level. However, the model development study may have limited to the used assumption set and understanding of the researcher, it may contribute theoretically, in terms of a new model proposition. Besides that, the development transparency and the proposed model and its data collection instrument may be the practical consideration points for the further studies.
\end{abstract}

Keywords: Model development, IS model, Technology readiness, Success model, System integration

\section{Introduction}

The IS performance issues has been one of the interesting themes for researchers and practitioners in the discipline since five decades ago. The people have been discussed the subject within the efficiency and effectiveness constructs of the computer-based business during the first decade. It has then been investigating by the scholars within some different themes, e.g., the utilization, satisfaction, readiness, acceptance, and the success constructs in the next periods [1-6]. It may be clearly seen that the constructs interrelate among others and some of the constructs are combined with another one. For example, the unified theory of acceptance and use of technology (UTAUT) [5] and the technology readiness and acceptance (TRA) [7] models. It is consistent with the indications of several previous studies [5, 7-11] which

This study was sponsored by the Centre for Research and Publication, the Syarif Hidayatullah State Islamic University Jakarta based on the Rector Decree No. Un.01/KPA/571/2017. indicated that many IS models are developed by referring to the previous theories rather than based on the empirical studies.

On the other side, many IS studies [1, 6, 12-14] elucidated that the IS performance studies are indispensable to be done continuously for improving the performance level, in regard to the technological risk management $[15,16]$ and the promised benefits of the IS implementations [17]. Accordingly, it is an interesting phenomenon how to continue the IS performance study by developing the new IS success model within the adoption, combination or adaptation of the previous IS models. The development may essential to explore the new opportunities of the IS performance improvement.

The purpose of the study was to explore the advanced influences of the technology readiness constructs towards the IS success ones and to develop an ISRS model in the context of IS integration performance. The objective was to explore the above-mentioned influences and to develop the ISRS model by adopting, combining, and adapting the technology readiness [18] and IS success [19] models. Following to the above-mentioned research programs, two research questions were then proposed in order to guide this exploratory study implementation.

Q-1. How to understand the relationship between the technology readiness constructs towards the IS success ones?

Q-2. How to combine the technology readiness model within the IS success model in the context of IS integration performance?

This paper is staked out within its five sections. The first one elucidates the research programs of the study. It is then followed by the literature review, research method, results and its discussions, and the conclusion parts in the second, third, fourth, and the fifth sections respectively.

\section{Literature Review}

It can be clearly seen that despite the fact that IS implementation is inevitable bring the beneficial impacts for the owners, but they have to be successful in the system implementation $[6,20]$. It means that the success of the IS implementation is the first challenge for the owners before obtaining the benefits. In contrast, besides the failure of the IS implementations will bring the financial loss; the failure may also affect the business survival of the system owners [21]. The previous IS success studies [1, 6, 
$10,12,22]$ indicated that the most success criteria of the IS development are related to the efficiency, effectiveness, user satisfaction, and the requirement fulfilment issues. Several IS survey [23, 24] and success [25, 26] studies revealed that one of the failure indications of IS developments is, however, the IS is successfully developed technically, but the system owners do not get its optimum benefits referring to the system requirements in the system development planning. For example, in the IS integration case. In this case, understanding the system integration and knowing the influenced factors may the early stage of the integration itself [27].

$\mathrm{Xu}$ et al. [21] indicated that in the context of how to support the integration of the business process and its services in an organization, the word of IS and information technology (TI) is interchangeable. Bouwman et al. [28] defined the technology is a combination of the telecommunication and computer technologies. The IS integration is inevitable to be the focus of many institutions [29], in regard to the autonomy, diversity, and distribution issues of the inter-organizational business functions [30]. Despite the fact that, many organizations ignore the internal readiness aspects of their IS development project [18].

On the other side, the IS performance issues have been one of the interesting themes for researchers and practitioners since five decades ago. They have been studied the subject within the efficiency and effectiveness constructs of the computer-based business during the first decade. Retrospectively, the subject has then been investigating by researchers and practitioners within some different themes, e.g., the utilization, satisfaction, readiness, acceptance, and the success constructs in the next periods [1-6]. In detail, the interrelationship among the constructs is indicated clearly within the used IS models. For instance, the UTAUT [5], TRA [7], IS success [19] models. Similarly, the indication is consistent with the tendencies of many IS studies [5, 7-11] which developed the research models by adopting, combining, and adapting the previous IS models.

\section{Research Method}

This model development study was performed throughout its four main stages (Fig. 1). First, the preliminary study (S1) was conducted by reviewing retrospectively the behavioural, organizational, and social themes of the IS studies, e.g., the usability, satisfaction, readiness, acceptance, and the success themes [2-5, 9-11, 13, 14, 18, $22,31-33$. Besides reviewing the literature, it was also performed to formulate the research programs. The stage was then followed by the modelling works in the second stage (S2). This model development stage was started by its first sub-stage (S2.1) for developing an assumption set based on the initiated and selected theories (see Table 1).

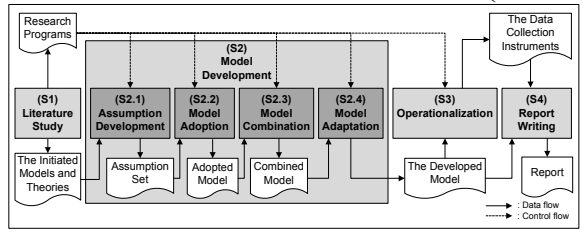

Fig. 1. Research procedure
Following to the developed set assumption, the Parasuraman and Colby's [18] technology readiness model and DeLone and McLean's [19] IS success model were then adopted, combined, and adapted in the second (S2.2), third (S2.3), and fourth (S2.4) sub-stages respectively. The developed model then was broke down into the research instrument level in the operationalization stage (S3). Lastly, the developed research model and its data collecting instrument were then proposed within the reporting stage, in terms of the research implementation Table I List of the basic models and theories

\begin{tabular}{|l|c|}
\hline \multicolumn{1}{|c|}{ List of the Basic Models and Theories } & References \\
\hline Information processing theory & {$[10,34]$} \\
\hline IS success model & {$[10,19,31,35,36]$} \\
\hline Technology readiness Model & {$[18]$} \\
\hline $\begin{array}{l}\text { Processional and causal models of a model } \\
\text { development }\end{array}$ & {$[31,37-39]$} \\
\hline
\end{tabular}

\section{Results And Discussion}

Fig. 2 presents the proposed ISRS model. The development was inspired by the previous model development researches [7,10] following to the model development tendencies of the Anfara and Mertz's [8] and Belout and Gauvreau's [40] studies, who indicated that most of the IS research models are tended to be developed practically using the previous models rather than based on the empirical studies. Generally, the model was developed by adopting, combining, and adapting the technology readiness [18] and IS success [19] models with its nine variables, i.e., Optimism (OPT), Innovativeness (INV), Discomfort (DCF), Insecurity (ISC), Information Quality (INQ), System Quality (SYQ), Service Quality (SVQ), User Satisfaction (USF), and System Integration Success (SIS). The first four variables were adopted from the Technology Readiness Model [18] and the rest ones were from the IS success model $[10,19,31]$.

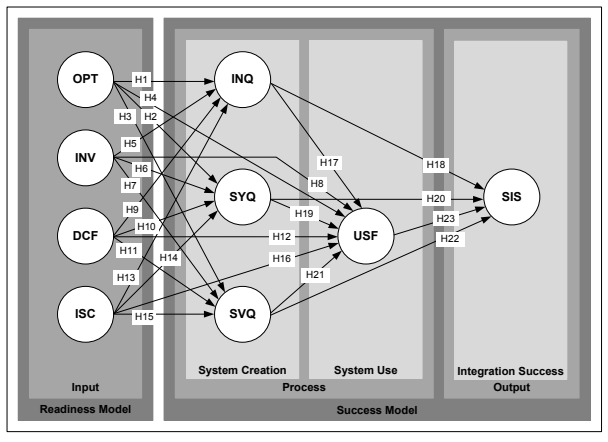

Fig. 2. The Proposed IS readiness and success model

Referring to the previous study [6, 10-12, 33] which employed the input-process-output (IPO) logic [34, 37] in the research model development, the researcher assumed that the IS integration process can also be assumed within the above-mentioned logic. In the context of the processional and causal model dimension, the scholar placed the model dimensions of the DeLone and McLean's [19] IS success model in the process and output dimensions of the IPO logic. In detail, the system creation 
and system use dimensions were assumed within the process one, in terms of a product life cycle [39]. Here, the integrated system was assumed as the output of the process. In terms of the processional and causal model of the system integration, the author believed that the system readiness is also one of the input factors [18, 41, 42]. In short, the technology readiness [18] and IS success [19] constructs were then adopted, combined and adapted by the researcher in the ISRS model development for assessing the system readiness factors towards the success of the IS integration. Table 2 shows the processional and causal dimension of the model development which was used to develop the 23 hypotheses, as it is described in the next paragraph.

Table II The processional and causal dimensions of the model development

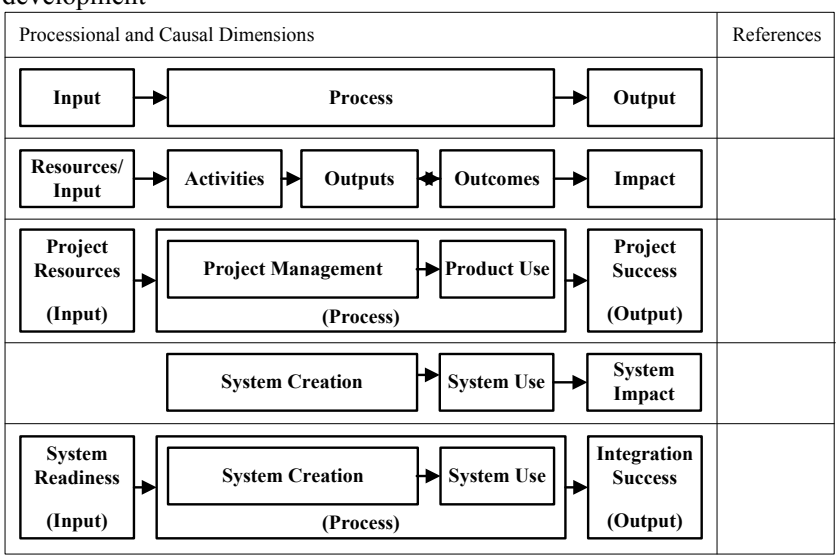

First, the previous studies $[18,41,42]$ indicated that the readiness constructs may influence IS implementation. In the context of the IPO logic of an IS integration, the constructs can be assumed within the input dimension of the logic. Therefore, in regard to the adoption and combination of the technology readiness [18] and IS success [19] the author hypothesized that each variable of the input dimension affects each variable of the process output (H1-H16).

Second, the processional and causal description of the DeLone and McLean's [19] IS success study revealed that the system creation dimension influences the system use one. This assumption is consistent with the product life cycle concept [39] whereas the product (system) use stage is affected by the product (system) creation one. Accordingly, the researcher hypothesized that each variable of the system creation dimension influences each variable of the system use one (H17, H19, and H21). In the context of the study whereas it will be implemented in the compulsory use environment, the author avoided the system use variable following the previous findings [14, $43,44]$.

Lastly, following to the processional and causal assumptions of the model development [10, 19, 31, 34, 37 , the output dimension was revealed to be sequentially affected by the process dimension. Thus, the author has also hypothesized that each variable of the process dimension influences the output dimension variable $(\mathrm{H} 18$,
$\mathrm{H} 20, \mathrm{H} 22$, and H23). Furthermore, the definitions of each variable, its broke down indicators and statements of the questionnaires can be seen in Table 3, Table 4, and Table 5 respectively.

Table III List Of The Variables [18, 19]
\begin{tabular}{|c|l|}
\hline Var. & \multicolumn{1}{c|}{ Definitions } \\
\hline OPT & The degree to believe that the IS will probably happen \\
\hline INV & $\begin{array}{l}\text { The degree to see that the IS is the advanced degree of the } \\
\text { system }\end{array}$ \\
\hline DCF & The degree to perceive that the IS is an uncomfortable thing \\
\hline ISC & $\begin{array}{l}\text { The degree to distrust that an IS integration is able to be } \\
\text { implemented properly and concerns about its potential harmful } \\
\text { consequences }\end{array}$ \\
\hline INQ & $\begin{array}{l}\text { The degree to which the produced information of the IS } \\
\text { consistently meets the requirements and expectations of } \\
\text { the users }\end{array}$ \\
\hline SYQ & $\begin{array}{l}\text { The degree to describe the quality of the content of the } \\
\text { IS }\end{array}$ \\
\hline SVQ & \begin{tabular}{l} 
The degree of the excellence of the IS services to its users \\
\hline USF
\end{tabular} $\begin{array}{l}\text { The degree of the satisfaction level of users during } \\
\text { utilizing the IS }\end{array}$ \\
\hline SIS & $\begin{array}{l}\text { The achievement of the IS based on its implementation } \\
\text { planning }\end{array}$ \\
\hline
\end{tabular}

Table IV List of the indicators [18, 19,33]

\begin{tabular}{|c|c|}
\hline Indicators & Definitions \\
\hline $\begin{array}{c}\text { Easiness } \\
\text { (OPT1) }\end{array}$ & $\begin{array}{l}\text { The degree related to the ability of a system for } \\
\text { providing a freedom from constrains, difficulties, } \\
\text { and troubles }\end{array}$ \\
\hline $\begin{array}{l}\text { Connectivity } \\
\text { (OPT2) }\end{array}$ & $\begin{array}{l}\text { The degree related to the ability of a system to } \\
\text { connect successfully with other systems }\end{array}$ \\
\hline $\begin{array}{l}\text { Efficiency } \\
\text { (OPT3) }\end{array}$ & $\begin{array}{l}\text { The degree related to the system achievement to } \\
\text { produce an output compared to the resources } \\
\text { needed to achieve the output }\end{array}$ \\
\hline $\begin{array}{l}\text { Effectiveness } \\
\text { (OPT4) }\end{array}$ & $\begin{array}{l}\text { The degree related to the system capability to } \\
\text { achieve its utilization goals }\end{array}$ \\
\hline $\begin{array}{l}\text { Productivity } \\
\text { (OPT5) }\end{array}$ & $\begin{array}{l}\text { The degree related to the system support for } \\
\text { producing output compared to the resources } \\
\text { needed to produce the output }\end{array}$ \\
\hline $\begin{array}{l}\text { Problem Solving } \\
\text { (INV1) }\end{array}$ & $\begin{array}{l}\text { The degree related to the system support for } \\
\text { finding solutions to problems }\end{array}$ \\
\hline $\begin{array}{l}\text { Independence } \\
\text { (INV2) }\end{array}$ & $\begin{array}{l}\text { The degree related to the system ability to support } \\
\text { its users free from the controls or influences }\end{array}$ \\
\hline $\begin{array}{l}\text { Challenge } \\
\text { (INV3) }\end{array}$ & $\begin{array}{l}\text { The degree related to the system support to } \\
\text { successfully deal with or achieve something } \\
\text { within a difficult situation or problem }\end{array}$ \\
\hline $\begin{array}{l}\text { Stimulation } \\
\text { (INV4) }\end{array}$ & $\begin{array}{l}\text { The degree related to the system support to } \\
\text { encourage something to happen, develop, or } \\
\text { improve }\end{array}$ \\
\hline $\begin{array}{l}\text { Competitiveness } \\
\text { (INV5) }\end{array}$ & $\begin{array}{l}\text { The degree related to the ability of a system to } \\
\text { support the users to be more successful than their } \\
\text { competitors }\end{array}$ \\
\hline $\begin{array}{l}\text { Complexity } \\
\text { (DCF1) }\end{array}$ & $\begin{array}{l}\text { The degree related to the system features that } \\
\text { confusing or difficult to be understood }\end{array}$ \\
\hline $\begin{array}{l}\text { Difficulty } \\
\text { (DCF2) }\end{array}$ & $\begin{array}{l}\text { The degree related to the condition of a system } \\
\text { which it is unable to be operated easily }\end{array}$ \\
\hline $\begin{array}{l}\text { Dependence } \\
\text { (DCF3) }\end{array}$ & $\begin{array}{l}\text { The degree related to the condition of a system } \\
\text { which needs the other parties to operate it }\end{array}$ \\
\hline $\begin{array}{l}\text { Lack of Support } \\
\text { (DCF4) }\end{array}$ & $\begin{array}{l}\text { The degree related to a system which it does not } \\
\text { have any, or enough, of the support in its } \\
\text { operation }\end{array}$ \\
\hline $\begin{array}{c}\text { Inappropriateness } \\
\text { (DCF5) }\end{array}$ & $\begin{array}{l}\text { The degree related to the state of being } \\
\text { inappropriate }\end{array}$ \\
\hline $\begin{array}{l}\text { Failure } \\
\text { (ISC1) }\end{array}$ & $\begin{array}{l}\text { The degree related to the possibility that a system } \\
\text { unpleasant or dangerous might happen }\end{array}$ \\
\hline $\begin{array}{l}\text { Threat } \\
\text { (ISC2) }\end{array}$ & $\begin{array}{l}\text { The degree related to the system situation that } \\
\text { could cause harm or danger }\end{array}$ \\
\hline
\end{tabular}


Table IV List Of The Indicators (Continued) $[18,19,33]$

\begin{tabular}{|c|c|}
\hline Indicators & Definitions \\
\hline $\begin{array}{l}\text { Reducing } \\
\text { Interaction } \\
\text { (ISC3) }\end{array}$ & $\begin{array}{l}\text { The degree related to the system implementation } \\
\text { which makes human interactions become less in } \\
\text { size, amount, and importance }\end{array}$ \\
\hline $\begin{array}{l}\text { Distraction } \\
\text { (ISC4) }\end{array}$ & $\begin{array}{l}\text { The degree related to the system utilization gets } \\
\text { attention and prevents people from concentrating } \\
\text { on something else }\end{array}$ \\
\hline $\begin{array}{l}\text { Incredulity } \\
\text { (ISC5) }\end{array}$ & $\begin{array}{l}\text { The degree related to the system hesitation of its } \\
\text { utilization }\end{array}$ \\
\hline $\begin{array}{l}\text { Accuracy } \\
\text { (INQ1) }\end{array}$ & $\begin{array}{l}\text { The appropriateness degree of the produced } \\
\text { information by the system with its real standard }\end{array}$ \\
\hline $\begin{array}{c}\text { Timeliness } \\
\text { (INQ2) }\end{array}$ & $\begin{array}{l}\text { The precision degree of the information processing } \\
\text { of the IS at the planned time duration }\end{array}$ \\
\hline $\begin{array}{l}\text { Completeness } \\
\text { (INQ3) }\end{array}$ & $\begin{array}{l}\text { The degree of the produced information by the IS } \\
\text { to be whole or without nothing missing part }\end{array}$ \\
\hline $\begin{array}{l}\text { Consistency } \\
\text { (INQ4) }\end{array}$ & $\begin{array}{l}\text { The tendency of the IS to still demonstrate the } \\
\text { same information within operations, services, } \\
\text { maintenances, or qualities }\end{array}$ \\
\hline $\begin{array}{l}\text { Relevance } \\
\text { (INQ5) }\end{array}$ & $\begin{array}{l}\text { The interrelationship degree of the produced } \\
\text { information by the IS with its subject matters }\end{array}$ \\
\hline $\begin{array}{l}\text { Ease-of-use } \\
\text { (SYQ1) }\end{array}$ & $\begin{array}{l}\text { The degree of a freedom by the IS from constrains, } \\
\text { difficulties, and troubles during its usages }\end{array}$ \\
\hline $\begin{array}{l}\text { Maintainability } \\
\text { (SYQ2) }\end{array}$ & $\begin{array}{l}\text { The degree related to the easiness of the IS in its } \\
\text { maintenance }\end{array}$ \\
\hline $\begin{array}{l}\text { Response time } \\
\text { (SYQ3) }\end{array}$ & $\begin{array}{l}\text { The degree related to the amount of time it takes } \\
\text { for the IS responding its user commands }\end{array}$ \\
\hline $\begin{array}{l}\text { Functionality } \\
\text { (SYQ4) }\end{array}$ & $\begin{array}{l}\text { The degree related to the IS can be operated } \\
\text { appropriately to the planned requirements }\end{array}$ \\
\hline $\begin{array}{c}\text { Safety } \\
\text { (SYQ5) }\end{array}$ & $\begin{array}{l}\text { The invulnerability degree of the IS from the } \\
\text { unexpected attacks, harms, or damages }\end{array}$ \\
\hline $\begin{array}{l}\text { Responsiveness } \\
\text { (SVQ1) }\end{array}$ & $\begin{array}{l}\text { The reaction degree of the IS to serve its users } \\
\text { within the suitable way, time and situation }\end{array}$ \\
\hline $\begin{array}{l}\text { Flexibility } \\
\text { (SVQ2) }\end{array}$ & $\begin{array}{l}\text { The adaptation degree of the IS to serve its users } \\
\text { appropriate to the required demands }\end{array}$ \\
\hline $\begin{array}{l}\text { Security } \\
\text { (SVQ3) }\end{array}$ & $\begin{array}{l}\text { The safety degree of an integrated system to serve } \\
\text { safely its users from attack, harm, or damage that } \\
\text { unexpected }\end{array}$ \\
\hline $\begin{array}{c}\text { Functionality } \\
\text { (SVQ4) }\end{array}$ & $\begin{array}{l}\text { The degree related to the service scope of the IS } \\
\text { appropriate to the functional requirements }\end{array}$ \\
\hline $\begin{array}{c}\text { Extension } \\
\text { (SVQ5) }\end{array}$ & $\begin{array}{l}\text { The degree related to the additional service scope } \\
\text { of the IS which exceed the functional requirements }\end{array}$ \\
\hline $\begin{array}{l}\text { Efficiency } \\
\text { (USF1) }\end{array}$ & $\begin{array}{l}\text { The user satisfaction degree of the IS based on the } \\
\text { system achievement to produce an output } \\
\text { compared to the resources needed to achieve the } \\
\text { output }\end{array}$ \\
\hline $\begin{array}{l}\text { Effectiveness } \\
\text { (USF2) }\end{array}$ & $\begin{array}{l}\text { The user satisfaction degree of the IS based on the } \\
\text { system capability to fulfil the user needs for } \\
\text { achieving their goals }\end{array}$ \\
\hline $\begin{array}{l}\text { Flexibility } \\
\text { (USF3) }\end{array}$ & $\begin{array}{l}\text { The user satisfaction degree of the IS related to the } \\
\text { adaptability of the system appropriate to the } \\
\text { required demands. }\end{array}$ \\
\hline $\begin{array}{c}\text { Overall } \\
\text { satisfaction } \\
\text { (USF4) }\end{array}$ & $\begin{array}{l}\text { The user satisfaction degree of the IS related to the } \\
\text { adequacy of the overall aspect of the system }\end{array}$ \\
\hline $\begin{array}{l}\text { IS Efficiency } \\
\text { (SIS1) }\end{array}$ & $\begin{array}{l}\text { The degree related to a comparison of the output } \\
\text { value of the IS and the resources needed to achieve } \\
\text { the output }\end{array}$ \\
\hline $\begin{array}{l}\text { IS Effectiveness } \\
\text { (SIS2) }\end{array}$ & $\begin{array}{l}\text { The degree related to the capability of the system } \\
\text { capability to fulfil the user needs for achieving } \\
\text { their goals }\end{array}$ \\
\hline $\begin{array}{l}\text { User } \\
\text { Satisfaction } \\
\text { (SIS3) }\end{array}$ & $\begin{array}{l}\text { The extent to which the IS helps users create value } \\
\text { for their business }\end{array}$ \\
\hline $\begin{array}{l}\text { Productivity } \\
\text { improvement } \\
\text { (SIS4) }\end{array}$ & $\begin{array}{l}\text { The degree related to the system support for } \\
\text { improving output compared to the resources } \\
\text { needed to produce the output }\end{array}$ \\
\hline $\begin{array}{l}\text { Competitive } \\
\text { advantage } \\
\text { (SIS5) }\end{array}$ & $\begin{array}{l}\text { The degree related to the favourable position of the } \\
\text { integrated IS users to be competed in the business } \\
\text { competitions }\end{array}$ \\
\hline
\end{tabular}

Table V List of the questionnaire statements

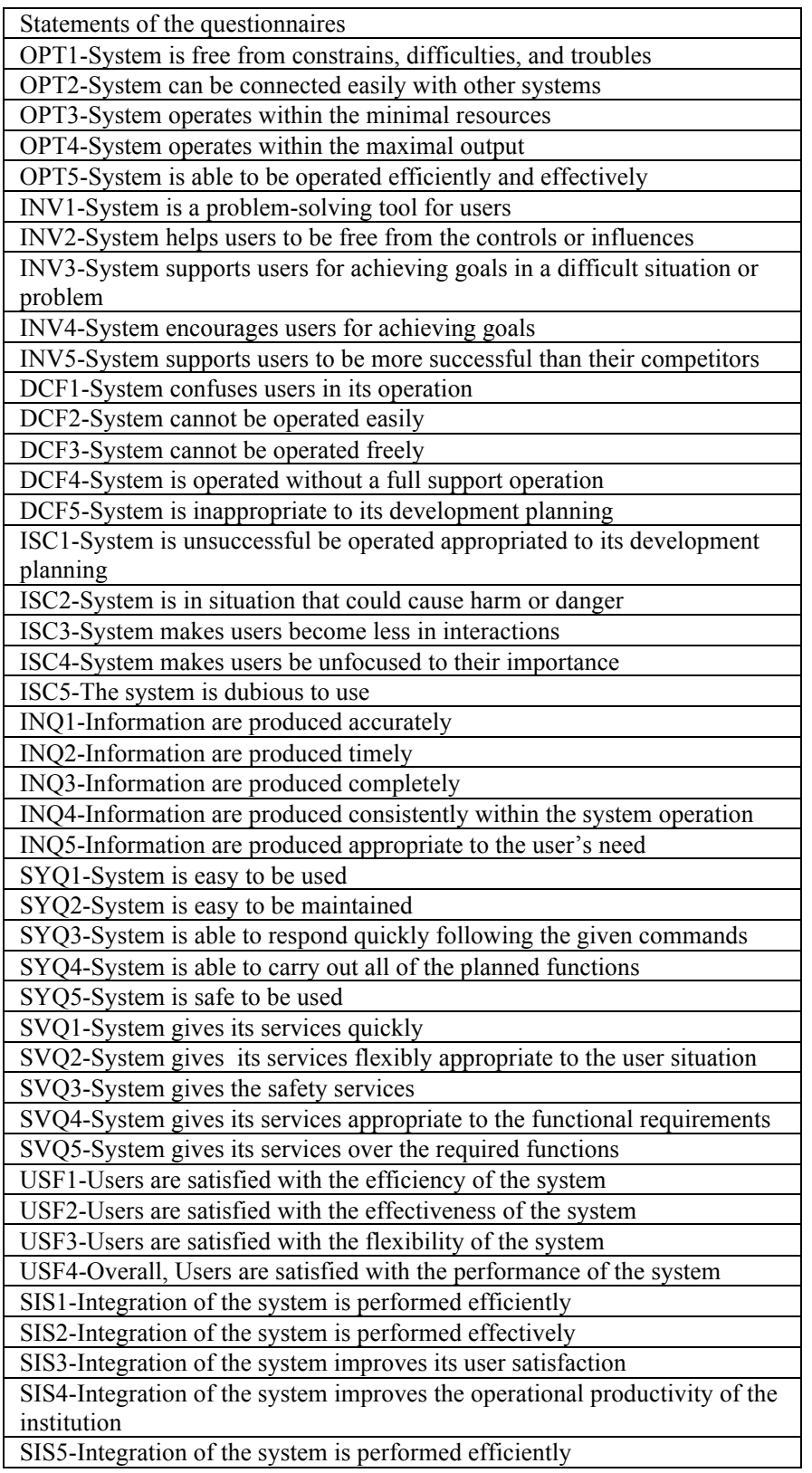

In respect of the above-mentioned research questions, the following descriptions are elucidated to respond both questions.

First, the relationship between the technology readiness and IS success constructs can be illustrated sequentially across a retrospective analysis of the usability, satisfaction, readiness, acceptance, and the success constructs of the computer-based system. For example, Robey [45] in the early era described that the user psychological reactions and organizational factors contribute to the system success. In the model development points, Venkatesh and Davis [5] extended the acceptance and use theories by combining both constructs within a combination model. On the other side, Lin, Shih, and Sher [7] have also integrated the technology readiness and acceptance constructs within a 
unified model. Similarly, adoptions of the system use and user satisfaction factors can also be seen in the DeLone and McLean's [19] IS success model. Clearly, the technology readiness and IS success constructs are connected within a sequential influence context. It is consistent with indications of the previous study [5, 7-11] which indicated that the adoption, combination, or adaptation of the prior models in the social studies is a common model development, in regard to explore the new model.

Second, the developed ISRS model (Fig. 2) is one of the new model developments. The adoption, combination, and the adaptation techniques of the technology readiness [18] and IS success [19] models implemented by the researcher based on the input-process-output (IPO) assumption [34, $37]$, as it was also presented by the previous studies $[6,10$ $12,33]$. In the context of IS integration assessment, the developed model has also broken down into its data collection instrument by adopting and adapting its study context.

In short, it can be clearly seen that the ISRS model development proved the new model development possibility by combining, adopting, and adapting the technology readiness [18] and IS success [19] constructs. Despite the fact that, the exploratory model development study was performed within the author understanding himself by adopting, combining, and adapting the two previous models [18, 19] based on the selected assumptions (Table 1), the study may contribute theoretically by proposing the ISRS model. Practically, transparency of the model development and the proposed model and its data collection instrument may useful for the further studies. Besides that, transparency of the model development process and credibility of the used basic models and theories may present the trust points of the study [38].

On the other side, the basic assumption of the model development, research method, and the author understanding may be limitations of the model development study. The differences in the assumption, method, and understanding may produce the different models. Thus, it is recommended that the study limitations may be considerations of the further studies.

\section{Conclusion}

The IS performance issues has been one of the interesting studies for researchers and practitioners since many decades ago. The studies indicated that many IS models are developed based on the previous theories rather than the empirical studies. Accordingly, the researcher developed the ISRS by adopting, combining, and adapting the technology readiness and IS success model, in terms of the IS integration assessment. The IPO logic and the processional and causal model of an IS success model were used by the author as the model development assumption. The proposed model consisted of the nine variables with 23 indicators. The researcher has also proposed 44 question items for the next questionnaires development. Besides this exploratory study may contribute theoretically in terms of the technology readiness and IS success model combination, the transparency development process and the proposed model and its data collection instrument may be a practical consideration points for the next studies.

Despite the fact that, the used assumption of the model development, research method, and the author understanding may be the study limitations. The other studies which used the different assumption, method and understanding may present the different propositions. In addition, the limitations may helpful for the further study, especially validity of the proposed model. Moreover, transparency of the model development process and credibility of the used basic models and theories may also be a consideration point of the model trust.

\section{References}

[1] T. D. Nguyen, T. M. Nguyen, and T. H. Cao, "Information Systems Success: A Literature Review," in International Conference on Future Data and Security Engineering, 2015, pp. 242-256.

[2] B. Sandra and F. Brenton, "Developers, Decision Makers, Strategists or Just End-users? Redefining End-User Computing for the 21st Century: A Case Study," Journal of Organizational and End User Computing (JOEUC), vol. 23, pp. 1-14, 2011.

[3] N. P. Melone, "A theoretical assessment of the user-satisfaction construct in information systems research," Management Science, vol. 36, pp. 76-91, 1990

[4] W. J. Doll and G. Torkzadeh, "The measurement of end-user computing satisfaction: theoretical and methodological issues," MIS Quarterly, pp. 5-10, 1991.

[5] V. Venkatesh and F. D. Davis, "A theoretical extension of the technology acceptance model: Four longitudinal field studies," Management Science, vol. 46, pp. 186-204, 2000.

[6] A. Subiyakto and A. R. Ahlan, "A coherent framework for understanding critical success factors of ICT project environment," in 2013 International Conference on Research and Innovation in Information Systems (ICRIIS), 2013, pp. 342-347.

[7] C. H. Lin, H. Y. Shih, and P. J. Sher, "Integrating technology readiness into technology acceptance: The TRAM model," Psychology \& Marketing, vol. 24, pp. 641-657, 2007.

[8] V. A. Anfara Jr and N. T. Mertz, Theoretical frameworks in qualitative research: Sage publications, 2014.

[9] V. Venkatesh, M. G. Morris, G. B. Davis, and F. D. Davis, "User acceptance of information technology: Toward a unified view," MIS Quarterly, pp. 425-478, 2003

[10] A. Subiyakto and A. R. Ahlan, "Implementation of Input-ProcessOutput Model for Measuring Information System Project Success," TELKOMNIKA Indonesian Journal of Electrical Engineering, vol. 12, pp. 5603-5612, 20142014.

[11] A. Subiyakto, A. R. Ahlan, S. J. Putra, and M. Kartiwi, "Validation of Information System Project Success Model," SAGE Open, vol. 5, pp. 1-14, 2015.

[12] S. J. Putra, A. Subiyakto, A. R. Ahlan, and M. Kartiwi, "A Coherent Framework for Understanding the Success of an Information System Project," TELKOMNIKA (Telecommunication, Computing, Electronics and Control), vol. 14, pp. 302-308, 2016 2016.

[13] A. Subiyakto, A. R. Ahlan, M. Kartiwi, S. J. Putra, and Y. Durachman, "The User Satisfaction Perspectives of the Information System Projects," Indonesian Journal of Electrical Engineering and Computer Science, vol. 4, 2016.

[14] A. Subiyakto, A. R. Ahlan, M. Kartiwi, and H. T. Sukmana, "Measurement of Information System Project Success Based on Perceptions of the Internal Stakeholders," International Journal of Electrical and Computer Engineering (IJECE), vol. 5, pp. 271279, April 20152015.

[15] A. N. Talet, R. Mat-Zin, and M. Houari, "Risk management and information technology projects," International Journal of Digital Information and Wireless Communications (IJDIWC), vol. 4, pp. $1-9,2014$ 
[16] A. R. Ahlan and Y. Arshad, "Information Technology Risk Management: The case of the International Islamic University Malaysia," Journal Of Research And Innovation In Information Systems, vol. 1, pp. 58-67, 2012.

[17] R. J. Kauffman, J. Liu, and D. Ma, "Technology investment decision-making under uncertainty," Information Technology and Management, vol. 16, pp. 153-172, 2015.

[18] A. Parasuraman and C. L. Colby, "An updated and streamlined technology readiness index: TRI 2.0," Journal of service research, vol. 18, pp. 59-74, 2015.

[19] W. H. DeLone and E. R. McLean, "The DeLone and McLean model of information systems success: a ten-year update," Journal of management information systems, vol. 19, pp. 9-30, 2003.

[20] Y. E. Chan and B. H. Reich, "IT alignment: what have we learned?," Journal of Information technology, vol. 22, pp. 297-315, 2007.

[21] X. Xu, W. Zhang, and R. Barkhi, "IT infrastructure capabilities and IT project success: a development team perspective," Information Technology and Management, vol. 11, pp. 123-142, 2010.

[22] A. Subiyakto, A. R. Ahlan, M. Kartiwi, and H. T. Sukmana, "Influences of the Input Factors towards Success of An Information System Project," TELKOMNIKA (Telecommunication Computing Electronics and Control), vol. 13, pp. 686-693, June 20152015.

[23] A. I. Almajed and P. Mayhew, "An empirical investigation of IT project success in developing countries," in Science and Information Conference (SAI), 2014, 2014, pp. 984-990.

[24] T. Clancy, "The Standish Group CHAOS Report," Project Smart, 2014.

[25] D. L. Hughes, Y. K. Dwivedi, A. C. Simintiras, and N. P. Rana, "Project Failure and Its Contributing Factors," in Success and Failure of IS/IT Projects, ed: Springer, 2016, pp. 3-25.

[26] R. Jrad and D. Sundaram, "Inter-organizational information and middleware system projects: success, failure, complexity, and challenges," 2015.

[27] R. L. Baskerville and A. T. Wood-Harper, "A critical perspective on action research as a method for information systems research," in Enacting Research Methods in Information Systems: Volume 2, ed: Springer, 2016, pp. 169-190.

[28] H. Bouwman, B. Van Den Hooff, and L. Van De Wijngaert, Information and communication technology in organizations: adoption, implementation, use and effects: Sage, 2005.

[29] W. He and L. Da Xu, "Integration of distributed enterprise applications: A survey," IEEE Transactions on Industrial Informatics, vol. 10, pp. 35-42, 2014.

[30] W. Hasselbring, "Information system integration," Communications of the ACM, vol. 43, pp. 32-38, 2000.

[31] S. Petter, W. DeLone, and E. McLean, "Measuring information systems success: models, dimensions, measures, and interrelationships," European journal of information systems, vol. 17, pp. 236-263, 2008

[32] A. Subiyakto, A. R. Ahlan, and H. T. Sukmana, "An Alternative Method for Determining Critical Success Factors of Information System Project," TELKOMNIKA Telecommunication, Computing, Electronics and Control, vol. 12, pp. 665-674, 20142014.

[33] A. Subiyakto, A. R. Ahlan, M. Kartiwi, and S. J. Putra "Measurement of the information system project success of the higher education institutions in Indonesia: a pilot study," International Journal of Business Information System, vol. 23, pp. 229-247, 2016.

[34] W. S. Davis and D. C. Yen, The Information System Consultant's Handbook: Systems Analysis and Design: CRC press, 1998.

[35] N. Urbach and B. Müller, "The updated DeLone and McLean model of information systems success," in Information systems theory, ed: Springer, 2012, pp. 1-18.

[36] T. D. Nguyen, T. M. Nguyen, and T. H. Cao, "A Conceptual Framework for IS Project Success," in International Conference on Context-Aware Systems and Applications, 2016, pp. 142-154.

[37] W. Kellogg, "Logic model development guide," Michigan: WK Kellogg Foundation, 2004.

[38] D. M. Eddy, W. Hollingworth, J. J. Caro, J. Tsevat, K. M. McDonald, and J. B. Wong, "Model transparency and validation a report of the ISPOR-SMDM Modeling Good Research Practices Task Force-7," Medical Decision Making, vol. 32, pp. 733-743, 2012.

[39] K. Jugdev and R. Müller, "A retrospective look at our evolving understanding of project success," Project Management Journal, vol. 36, pp. 19-31, 2005.

[40] A. Belout and C. Gauvreau, "Factors influencing project success: the impact of human resource management," International journal of project management, vol. 22, pp. 1-11, 2004.

[41] W. Waheduzzaman and S. J. Miah, "Readiness assessment of egovernment: a developing country perspective," Transforming Government: People, Process and Policy, vol. 9, pp. 498-516, 2015.

[42] S. I. Mahdzur and J. Salim, "Information System Integration Factors in Organization: Towards Government Information Systems Sustainability," Journal of Theoretical \& Applied Information Technology, vol. 71, 2015.

[43] P. Seddon and M.-Y. Kiew, "A partial test and development of DeLone and McLean's model of IS success," Australasian Journal of Information Systems, vol. 4, 1996.

[44] J. Floropoulos, C. Spathis, D. Halvatzis, and M. Tsipouridou, "Measuring the success of the Greek taxation information system," International Journal of Information Management, vol. 30, pp. 4756, 2010.

[45] D. Robey, "User attitudes and management information system use," Academy of Management Journal, vol. 22, pp. 527-538, 1979 . 